\title{
POSTER: The use of Augmented Reality in the classroom
}

\author{
Gabriel Bio Guerra \\ Instituto Federal de Educação, Ciência \\ e Tecnologia de São Paulo \\ Cubatão, Brazil \\ bioguerrabg@gmail.com
}

\author{
Matheus Ferreira da Costa \\ Instituto Federal de Educação, Ciência \\ e Tecnologia de São Paulo \\ Cubatão, Brazil \\ matheus.ferreira@aluno.ifsp.edu.br
}

\author{
Matheus Henrique Palinkas dos Santos \\ Instituto Federal de Educação, Ciência \\ e Tecnologia de São Paulo \\ Cubatão, Brazil \\ matheuspalinkas31@gmail.com
}

\begin{abstract}
Augmented reality is a technology that has been growing every day, being used in various fields, such as architecture, games and medicine, and because of this growth, several applications of this resource arise. With this in mind, this project seeks to apply augmented reality in the classroom by the use of smartphones. Our intention is to show that a device that can hinder learning, can also helps a lot when applied in a favorable way to learning.
\end{abstract}

Basically, with an easy-to-use mobile phone application, students will be able to see pictures from their textbook in three dimensions and animated, thus making learning more dynamic and playful. By not modifying the content of the textbook, the application can be used in several schools, requiring the application and the textbook for which it was developed.

Keywords - Augmented Reality, Mobile Devices, AR applied to Teaching.

\section{INTRODUCTION}

More and more, technology has been part of our daily lives and this is due to the constant technological evolution that always aims to facilitate the life of the population. This evolution allows the emergence of new technologies such as Augmented Reality and Virtual Reality. Although augmented reality seems new, it had its first manifestation in the 1960s with the inventions of Ivan Sutherland. Since then, it has been explored and every day a new application emerges. One of the possibilities of implementation of Augmented Reality is in education, with the use of interactive textbooks in which, when pointing a smartphone camera at some image printed in the book, a 3D model (animated or not) of the object represented in the photo appears on the device's screen.

\section{OBJECTIVES}

Our project aims to improve the quality of teaching using augmented reality in students' mobile devices, which are considered the greatest distractions in the classroom. For this to be possible we are developing an application of augmented reality, so that students can use their devices for visualization and interaction with previously catalogued 3D figures, thus improving their understanding of the proposed subject. With this it is expected an improvement in the performance of students who use the application during classes, because it is known that a more dynamic and interactive class can make students more participatory in future classes, consequently, it is expected to change the method of understanding the student, in which he no longer only practice memorization and starts to build their line of reasoning.

\section{METHODOLOGY}

Following the analysis of the current education system, market researches, and interviews, it has been determined that the use of mobile devices as a distraction is a problem that many schools today suffer, so the application can transform something that is considered a problem during the class in a tool to help the students' understanding.

Using the information collected, a book and a subject were adopted as a pilot for the introduction of technology. "Física em contextos 2 - Ensino Médio" was the textbook chosen from the subject of Physics because it presents characteristics favorable to the introduction of Augmented Reality, and due to the possibilities found in using technology to improve the understanding of the figures in the book.

The application was made using tools such as Vuforia (SDK containing augmented reality tools and marker storage database), Unity (software used for game creation and in this case for exporting the Android extension) and Blender 3D (software for creating 3D objects and animations).

It's expected that the results and opinions about the interventions will be collected after the application implementations in the classrooms. It is intended to create Likert scale forms and conduct interviews with students and also teachers before and after the implementations of the class for pointing improvements and criticism.

\section{DISCUSSION OF RESULTS}

The main result is expected to restructure the education system, introduce to students and teachers the power of the technology, and how it can improve our routine actions.

Feedback from analysis and statistics from schools will be necessary to discuss the positive and negative aspects of this technological manifestation in our current education system. Improvements should be made based on this data, so that the project spreads in the best possible way, being accessible and useful to all who wish to take advantage of this technology.

It is also necessary to know if the students and teachers are able to succeed this intervention, if the necessary devices are accessible to the beneficiaries and so on, taking into account that the project does not change the programmatic content of any curriculum component, only changes the way these contents can be taught. 


\section{CONCLUSION}

This study concluded that augmented reality is an emerging technology and has many potentials to be implemented in many areas. Its ease of production and implementation, explain why several companies have been coming up with new ideas on how to exploit this technology.

The introduction of augmented reality in the education system intends to revolutionize the way the student study during his routine, he will not just memorize the material that is being taught, he will create his line of thinking using an augmented reality application, which is something intuitive and effective. After researches with students and teachers were concluded that the visualization of objects in $3 \mathrm{D}$, which is better than the $2 \mathrm{D}$ representations found in the books, facilitates comprehension.

This study also shows that technological advancement can bring incredible tools to education and transform a problem in improvement, the use of the mobile device to integrate the augmented reality in the class is a good example, and it transformed a distraction in something useful. With augmented reality, teachers can take intuitive classes and hold students' attention, as well as make it easier to explain content.

Using the application created in this study, we made market research in Instituto Federal de Educação, Ciência e Tecnologia de São Paulo Campus Cubatão with students and teachers were concluded that the idea is very welcome and it would solve several problems faced by them in the classroom nowadays.

\section{REFERENCES}

[1] BERGAMASCHI, Marcelo Pereira; MORAIS, Thamires Martins Augusto de. Estudo sobre a utilização de VUFORIA e Unity 3D com RA para dispositivos móveis. 2014. Available at: 〈http://www.lbd.dcc.ufmg.br/colecoes/wrva/2014/031.pdf〉. Accessed on: July 2nd, 2019.

[2] Vuforia Developer Library in Getting Started website. Available at: <https://library.vuforia.com/getting-started.html>. 2011-2018. Accessed on: July 5th, 2019.

[3] MEGALI, Tin. Realidade Aumentada Estilo Pokémon GO com Vuforia. Available at: <https://code.tutsplus.com/pt/tutorials/introducingaugmented-realitywith-vuforia--cms-27160>. 2016. Accessed on: August 12th, 2019.

[4] CREIGHTON, Ryan Henson. Unity 3D Game Development by Example. 1st Ed, Packt Publishing Ltd. Solihull, United Kingdom, 2010.

[5] Rivello Multimedia Consulting website. Available at: <http://www.rivellomultimediaconsulting.com/unity3daugmentedreality/>. 2013. Accessed on: May 24th, 2019.

[6] Realidade Aumentada website. Available: <https://sites.google.com/site/realidadeaumentada01canoas/home/hist ori a-da-realidade-aumentada>. 2018. Accessed on: May 24th, 2019.

[7] HAUTSCH, Oliver. Como funciona a realidade aumentada. Available at: <https://www.tecmundo.com.br/realidade-aumentada/2124 comofunciona-a-realidade-aumentada.htm>. 2009. Accessed on: May 19th, 2019.

[8] Nop website. Available at: $<$ https://noperation.wordpress.com/2014/11/09/realidadeaumentadacom-vuforia-em-unity3d-instalacao-e-exemplo-olamundo/>. 2014. Accessed on: June 5th, 2019.

[9] Vuforia engine website. Available at: $<$ https://www.vuforia.com/features.html>. 2018. Accessed on: June 5 th, 2019. 